\title{
Introduction to the 2008 Circum-Arctic Resource Appraisal (CARA) Professional Paper
}

Chapter A of

The 2008 Circum-Arctic Resource Appraisal

Professional Paper 1824 
Cover. View to the east of the Lisburne well during active drilling in July 1979, Ivotuk Hills, northern Alaska. U.S. Geological Survey photo by Thomas Moore. 


\section{Introduction to the 2008 Circum-Arctic Resource Appraisal (CARA) Professional Paper}

By Donald L. Gautier and Thomas E. Moore

Chapter A of

The $\mathbf{2 0 0 8}$ Circum-Arctic Resource Appraisal

Edited by T.E. Moore and D.L. Gautier

Professional Paper 1824

U.S. Department of the Interior

U.S. Geological Survey 


\title{
U.S. Department of the Interior RYAN K. ZINKE, Secretary
}

\section{U.S. Geological Survey William H. Werkheiser, Acting Director}

\author{
U.S. Geological Survey, Reston, Virginia: 2017
}

For more information on the USGS — the Federal source for science about the Earth, its natural and living resources, natural hazards, and the environment-visit https://www.usgs.gov or call 1-888-ASK-USGS.

For an overview of USGS information products, including maps, imagery, and publications, visit https://store.usgs.gov.

Any use of trade, firm, or product names is for descriptive purposes only and does not imply endorsement by the U.S. Government.

Although this information product, for the most part, is in the public domain, it also may contain copyrighted materials as noted in the text. Permission to reproduce copyrighted items must be secured from the copyright owner.

Suggested citation:

Gautier, D.L., and Moore, T.E., 2017, Introduction to the 2008 Circum-Arctic Resource Appraisal (CARA) professional paper, chap. A of Moore, T.E., and Gautier, D.L., eds., The 2008 Circum-Arctic Resource Appraisal: U.S. Geological Survey Professional Paper 1824, 9 p., https://doi.org/10.3133/pp1824A.

ISSN 2330-7102 (online) 


\section{The 2008 Circum-Arctic Resource Appraisal}

\section{Chapters}

A. Introduction to the 2008 Circum-Arctic Resource Appraisal (CARA) Professional Paper By Donald L. Gautier and Thomas E. Moore

B. Methodology for Assessment of Undiscovered Oil and Gas Resources for the 2008 Circum-Arctic Resource Appraisal

By Ronald R. Charpentier

\section{North America}

C. Geology and Assessment of Undiscovered Oil and Gas Resources of the Chukchi Borderland Province, 2008

By Kenneth J. Bird and David W. Houseknecht

D. Geology and Assessment of Undiscovered Oil and Gas Resources of the Hope Basin

Province, 2008

By Kenneth J. Bird, David W. Houseknecht, and Janet K. Pitman

E. Geology and Assessment of Undiscovered Oil and Gas Resources of the Arctic Alaska Petroleum Province, 2008

By David W. Houseknecht, Kenneth J. Bird, and Christopher P. Garrity

F. Geology and Assessment of Undiscovered Oil and Gas Resources of the Yukon Flats Basin Province, 2008

By Kenneth J. Bird and Richard G. Stanley

G. Geology and Assessment of Undiscovered Oil and Gas Resources of the Northwest Canada Interior Basins Province, Arctic Canada, 2008

By Marilyn E. Tennyson and Janet K. Pitman

H. Geology and Assessment of Undiscovered Oil and Gas Resources of the Franklinian Shelf Province, Arctic Canada and North Greenland, 2008

By Marilyn E. Tennyson and Janet K. Pitman

I. Geology and Assessment of Undiscovered Oil and Gas Resources of the Sverdrup Basin Province, Arctic Canada, 2008

By Marilyn E. Tennyson and Janet K. Pitman

\section{Greenland}

J. Geology and Assessment of Undiscovered Oil and Gas Resources of the West GreenlandEast Canada Province, 2008

By Christopher J. Schenk 
K. Geology and Assessment of Undiscovered Oil and Gas Resources of the East Greenland Rift Basins Province, 2008

By Donald L. Gautier

\section{North Atlantic Ocean}

L. Geology and Assessment of Undiscovered Oil and Gas Resources of the Jan Mayen Microcontinent Province, 2008

By Thomas E. Moore and Janet K. Pitman

\section{Eurasia}

M. Geology and Assessment of Undiscovered Oil and Gas Resources of the Mezen' Basin Province, 2008

By Timothy R. Klett and Janet K. Pitman

N. Geology and Assessment of Undiscovered Oil and Gas Resources of the Timan-Pechora Basin Province, Russia, 2008

By Christopher J. Schenk

0. Geology and Assessment of Undiscovered Oil and Gas Resources of the East Barents Basins Province and the Novaya Zemlya Basins and Admiralty Arch Province

By Timothy R. Klett

P. Geology and Assessment of Undiscovered Oil and Gas Resources of the North Kara Basins and Platforms Province, 2008

By Timothy R. Klett and Janet K. Pitman

0. Geology and Assessment of Undiscovered Oil and Gas Resources of the Northern West Siberian Mesozoic Composite Total Petroleum System of the West Siberian Basin Province, Russia, 2008

By Christopher J. Schenk

R. Geology and Assessment of Undiscovered Oil and Gas Resources of the Yenisey-Khatanga Basin Province, 2008

By Timothy R. Klett and Janet K. Pitman

S. Geology and Assessment of Undiscovered Oil and Gas Resources of the Northwest Laptev Sea Shelf Province, 2008

By Timothy R. Klett and Janet K. Pitman

T. Geology and Assessment of Undiscovered Oil and Gas Resources of the Lena-Anabar Basin Province, 2008

By Timothy R. Klett and Janet K. Pitman 
U. Geology and Assessment of Undiscovered Oil and Gas Resources of the Tunguska Basin Province, 2008

By Christopher J. Wandrey and Timothy R. Klett

V. Geology and Assessment of Undiscovered Oil and Gas Resources of the Lena-Vilyui Basin Province, 2008

By Timothy R. Klett and Janet K. Pitman

W. Geology and Assessment of Undiscovered Oil and Gas Resources of the Laptev Sea Shelf Province, 2008

By Timothy R. Klett and Janet K. Pitman

X. Geology and Assessment of Undiscovered Oil and Gas Resources of the Zyryanka Basin Province, 2008

By Timothy R. Klett and Janet K. Pitman

Y. Geology and Assessment of Undiscovered Oil and Gas Resources of the East Siberian Sea Basin Province, 2008

By Kenneth J. Bird, David W. Houseknecht, and Janet K. Pitman

Z. Geology and Assessment of Undiscovered Oil and Gas Resources of the Vilkitskii Basin Province, 2008

By Kenneth J. Bird, David W. Houseknecht, and Janet K. Pitman

AA. Geology and Assessment of Undiscovered Oil and Gas Resources of the Long Strait Province, Russian High Arctic, 2008

By Kenneth J. Bird, David W. Houseknecht, and Janet K. Pitman

\section{Arctic Ocean}

BB. Geology and Assessment of Undiscovered Oil and Gas Resources of the Amerasia Basin Petroleum Province, 2008

By David W. Houseknecht, Kenneth J. Bird, and Christopher P. Garrity

CC. Geology and Assessment of Undiscovered Oil and Gas Resources of the LomonosovMakarov Province, Central Arctic Ocean, 2008

By Thomas E. Moore, Kenneth J. Bird, and Janet K. Pitman

DD. Geology and Assessment of Undiscovered Oil and Gas Resources of the Eurasia Basin Province, Eastern Arctic Ocean, 2008

By Thomas E. Moore and Janet K. Pitman 


\section{Contents}

The 2008 Circum-Arctic Resource Appraisal Chapter List ............................................................................... iii

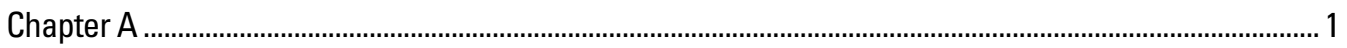

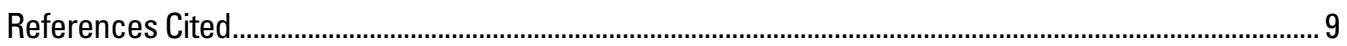

\section{Figures}

1. Provinces in the Circum-Arctic Resource Appraisal........................................................3

2. Provinces in the Circum-Arctic Resource Appraisal color-coded by mean estimated undiscovered gas

3. Provinces in the Circum-Arctic Resource Appraisal color-coded for mean estimated undiscovered oil.

4. Assessment units in the Circum-Arctic Resource Appraisal color-coded by assessed probability of the presence of at least one undiscovered oil and/or gas field with recoverable resources greater than 50 million barrels of oil equivalent

\section{Table}

1. Summary of mean estimates of undiscovered petroleum resources for the provinces of the 2008 Circum-Arctic Resource Appraisal 




\title{
Chapter A
}

\section{Introduction to the 2008 Circum-Arctic Resource Appraisal (CARA) Professional Paper}

\author{
By Donald L. Gautier and Thomas E. Moore
}

The amount of yet-to-find oil and gas in the high northern latitudes is one of the great uncertainties of future energy supply. The possibility of extensive new petroleum developments in the Arctic Ocean is of interest to the Arctic nations, to petroleum companies, and to those concerned with the delicate and changing Arctic environment. The U.S. Geological Survey (USGS) 2008 Circum-Arctic Resource Appraisal (CARA) had the express purpose of conducting a geologically based assessment of undiscovered petroleum north of the Arctic Circle, thereby providing an initial evaluation of resource potential.

The CARA project formally began in the summer of 2004 with a technical workshop in Ilulissat, Greenland, organized by GEUS (the Geological Survey of Denmark and Greenland) and USGS. Following geological map compilation, work first focused on offshore areas of northeast Greenland for proof-of-concept of assessment methodology and protocols. Initial findings of the complete USGS CARA were released in August 2008, first at the National Press Club in Washington, D.C., and a short time later at the International Geological Congress in Oslo, Norway. Those first public presentations revealed the results of a five-year effort that involved numerous USGS scientists, scientist emeriti, contractors, and scientific collaborators from Canada, Denmark, Germany, Norway, and Russia. The USGS part of the project was funded largely by the USGS Energy Resources Program, with additional financial support from the U.S. Department of Energy for studies of the Russian Arctic. The Geological Survey of Canada, GEUS, the Norwegian Petroleum Directorate, the Bundesanstalt für Geowissenschaften und Rohstoffe, and the U.S. Minerals Management Service (now the Bureau of Ocean Energy Management and the Bureau of Safety and Environmental Enforcement) were all active participants in the CARA. Academics from Moscow and Saint Petersburg, working on contract to the USGS, provided Russian resource information. The CARA project culminated in a paper published in Science on May 29, 2009 (Gautier and others, 2009).

Much of the technical documentation for the CARA has been placed in the public domain, largely outside of the USGS publication network: Ken Peters and others published a paper called "Circum-Arctic petroleum systems identified using decision-tree chemometrics" in the American Association of Petroleum Geologists (AAPG) Bulletin in 2007. Arthur Grantz and others published "Maps showing the sedimentary successions of the Arctic Region that may be prospective for hydrocarbons" through AAPG in 2009 (the second edition was released in 2010). Donald Gautier and others summarized the methods and results in an article called "Assessment of undiscovered oil and gas in the Arctic," published in Science in 2009. John Schuenemeyer and Gautier published "Aggregation methodology for the Circum-Arctic Resource Appraisal" in Mathematical Geoscience in 2010. Fifteen CARA-related papers by USGS or USGS-affiliated scientists constituted an important part of the 2011 Geological Society of London Memoir 35, called "Arctic petroleum geology" (Spencer and others, 2011). Other CARA publications have been released by the USGS. Notable among these are the "Assessment of undiscovered petroleum resources of the Amerasia Basin petroleum province" and the "Assessment of undiscovered petroleum resources of the Arctic Alaska petroleum province," both published by David Houseknecht, Kenneth Bird, and Chris Garrity in 2012, and both of which have been included in this Professional Paper as well. The "Database for assessment unit-scale analogs (exclusive of the United States)," by Ronald Charpentier, Timothy Klett, and Emil Attanasi, was published in 2008; and "Circum-Arctic Resource Appraisal (north of the Arctic Circle) assessment units," the Geographic Information System (GIS) data for the CARA, was released by the USGS as an online publication in 2009.

The objective of this volume is to present a complete record of the geologic information, methodology, and reasoning that led to the assessment results of the CARA project. Although knowledge of the Arctic has continued to expand rapidly as a result of new scientific investigations and increasing awareness of the accessibility of resources in the Arctic by governments and industry, the information contained in these chapters captures only what was known and evaluated at the time of the CARA. Thus, the volume provides a record of the thinking used to conduct the assessment and establishes a benchmark against which future evaluations of Arctic petroleum resources can be measured. 
Although complex in detail, the basic assessment strategy was relatively simple. The Arctic region was divided into a number of assessment units (AUs), each defined by specific geological conditions, and then a methodology was applied for estimating the sizes and numbers of undiscovered oil and gas accumulations appropriate for the geological conditions in the area of each AU. Because of the absence of wells and seismic data in many parts of the Arctic, the methodology for estimating the sizes and number of undiscovered oil and gas accumulations relied heavily on analogue modeling whereby the assessment units in Arctic sedimentary basins were compared to geologically similar but better known petroleum basins elsewhere in the world. This methodology, described by Ronald Charpentier in chapter B, used a probabilistic approach that was applied on a consensus basis by a team of scientists that had a diverse set of skills and experience in geology, geophysics, geochemistry, statistics, and GIS.

The sedimentary basins that may be prospective for hydrocarbons in the Arctic were mapped by Grantz and others $(2010,2011)$ and organized into 33 petroleum provinces for the purpose of the CARA assessment (fig. 1). Each province was subdivided into one or more assessment units according to the petroleum systems known or inferred to be present. Discussions of the petroleum geology, the parameters used for assessment, and the results of the assessments for 29 of the petroleum provinces, presented on a province-by-province basis, form the core of this volume (note that discussions for two provinces, the East Barents and Novaya Zemlya and Admiralty Arch, are combined in the same chapter). Sixteen of these provinces lie in Eurasia, seven in North America, two in Greenland, and four in the Arctic and North Atlantic Ocean basins. As noted above, two of the North American provinces were discussed in previously released USGS publications (Houseknecht and others, 2012a,b); these papers have been included as chapters of this volume. In addition, four more provinces are not represented here: two of them in Norwegian territory (the Norwegian Margin and the Barents Platform Provinces), one in offshore Greenland (North Greenland Sheared Margin), and one in northeastern Russia (North Chukchi-Wrangel Foreland Basin). Documentation of the assessment of the western part of the North Greenland Sheared Margin Province (the Lincoln Sea basin) was published by Sørensen and others (2011).

The CARA assessments of the two Norwegian basins, in contrast to every other CARA estimate, were based upon resource assessments completed and published by the Norwegian Petroleum Directorate (NPD). The unusual decision to modify existing NPD studies rather than doing original USGS assessments was based on the judgment that, given the high technical quality of the regularly updated NPD assessments (Norwegian Petroleum Directorate, 2009) the CARA team could not improve them within the scope of the 2008 study.

Much has changed in the Arctic since completion of the CARA in terms of climate and ice conditions, politics of territorial boundaries, and technology and economics of petroleum exploration and production. Although in 2009 there was a general awareness of the potential effect of anthropogenic climate change on the Arctic, its magnitude and rate were not fully appreciated at the time and are still not fully understood. The rapid disappearance of multi-year sea ice has the potential to make the entire Arctic basin navigable within a few years, bringing with it the possibility of widespread development. On the other hand, global climate change also has resulted in an exponential increase in climaterelated Arctic research and in worldwide concern about reliance on fossil fuels.

The science and politics of the United Nations Convention on the Law of the Sea (UNCLOS) were already well underway when the CARA was completed. As of 2017, each of the Arctic nations except the United States has ratified the UNCLOS. Norway ratified the convention in 1996, followed by Russia in 1997, Canada in 2003, and Denmark in 2004. Each of the ratifying countries has now submitted claims to Arctic territory. The Canadian, Russian, and Danish submittals all lay claim to the geographic North Pole. At the same time, some important Arctic territorial issues are outside of the UNCLOS process. For example, Arctic territorial disagreements between the United States and Canada remain unresolved. However, the area of overlapping claims along the international boundary between Norway and Russia in the Barents Sea, which was a subject of great concern at the time of the initial CARA release, has been largely and peacefully resolved by bilateral agreement. That agreement has done much to facilitate data gathering that reduces the resource uncertainty and clarifies Barents Sea development options for both countries.

In 2008, large-scale development of Arctic petroleum seemed to be in the offing; the unexplored north was seen as one of the few possible localities for globally significant petroleum discoveries, and environmental concern about the manner of development was an urgent matter. Indeed, one of the reasons the CARA drew so much public attention at the time of its completion was the then-current context of anticipated petroleum shortages and perceived offshore resource opportunities in the Arctic nations. However, in spite of the unprecedented retreat of Arctic sea ice and rapid advancements in drilling and production technology, widespread development of Arctic resources now seems even more remote than it did in 2008.

The intense development of shale-oil and shale-gas resources in the United States and Canada has revolutionized the global oil and gas market and shifted the perception of future resource availability. At the time of this writing (September 2017), few would argue that a dire shortfall of oil or gas is imminent or even that Arctic petroleum development is inevitable. One of the largest petroleum fields in the world, the supergiant Shtokman gas and condensate field, discovered in 1988 in the Russian Barents Sea, has yet to be put on regular production and its economics remain questionable. Perhaps even more significantly, Royal Dutch Shell recently reported that it failed to find significant quantities of oil beneath the large gas accumulation discovered in its Burger prospect in 1990 and consequently terminated its Chukchi Sea exploration program because of high costs, the 


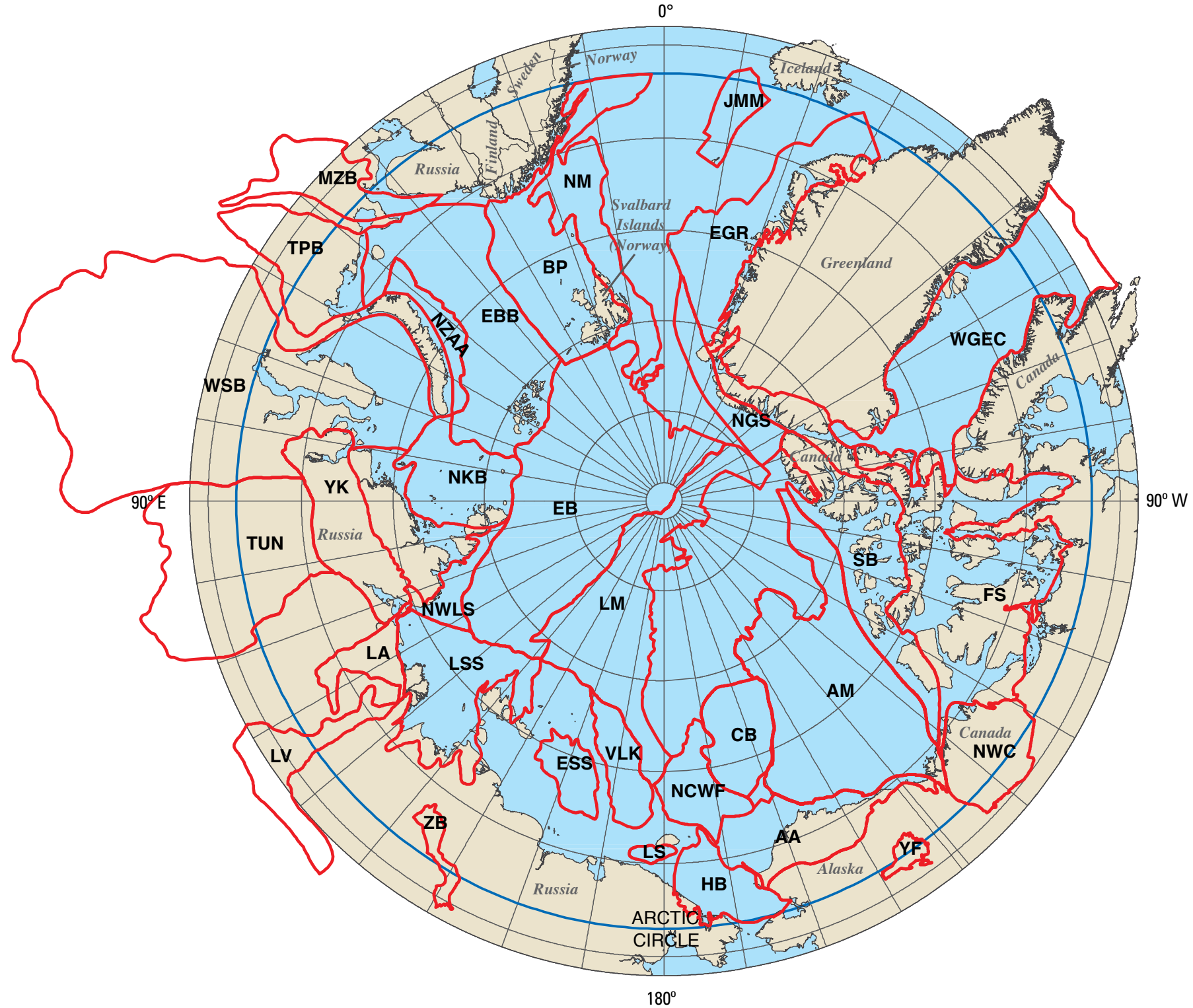

CARA Province Abbreviations

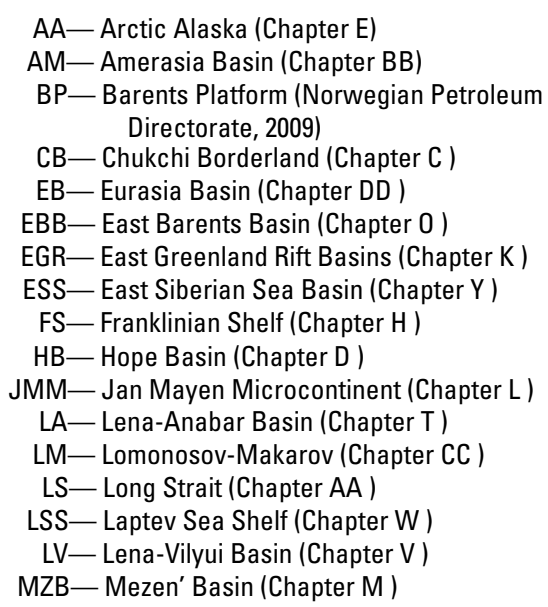

NCWF- North Chukchi-Wrangel Foreland Basin (assessed, not included in volume)

NGS - North Greenland Sheared Margin (Lincoln Sea-Sørensen and others, 2012; Wandel Sea-assessed, not included in volume)

NKB - North Kara Basins and Platforms (Chapter P)

NM- Norwegian Margin (Norwegian Petroleum Directorate, 2009)

NWC - Northwest Canada Interior Basins (Chapter G )

NWLS - Northwest Laptev Sea Shelf (Chapter S)

NZAA - Novaya Zemlya Basins and Admiralty Arch (Chapter 0 )

SB - Sverdrup Basin (Chapter I)

TPB - Timan-Pechora Basin (Chapter N)

TUN-Tunguska Basin (Chapter U )

VLK - Vilkitskii Basin (Chapter Z)

WGEC - West Greenland-East Canada (Chapter J)

WSB - West Siberian Basin (Chapter Q)

YF- Yukon Flats Basin (Chapter F)

YK-Yenisey-Khatanga Basin (Chapter R )

ZB-Zyryanka Basin (Chapter X)

Figure 1. Provinces in the Circum-Arctic Resource Appraisal. Province abbreviations are the same as in table 1. 
regulatory environment, and the low price of oil and gas on the world market. Shell had begun exploration in the Chukchi Sea in 1990 and invested more than $\$ 5$ billion in its recent exploration program there. Indeed, as of now, even the most determined and deep-pocketed exploration companies have largely shifted their attention away from the Arctic.

Vast amounts of new information have accumulated since the 2008 completion of the CARA. Large oil accumulations have been discovered in both the Norwegian and Russian sectors of the Barents Sea and in the Pechora Sea. Other large discoveries have recently been found in onshore northern Alaska, mostly by smaller companies eager to explore in frontier basins that have good petroleum geology characteristcs and are located close to infrastructure. On the other hand, an exploratory drilling campaign in eastern Baffin Bay failed to find significant recoverable hydrocarbons, cooling exploration interest there and suggesting that western Greenland will not be a major petroleum producer any time soon. At the same time, geological and geochemical studies on the continental shelf offshore of northeastern Greenland seem to reinforce the potential for large undiscovered resources in that environmentally difficult region. All of this has improved geological understanding and reduced the uncertainty surrounding Arctic resource potential.

In spite of all the changes and new information, the principal findings of the CARA remain intact:

1. The resource potential of the Arctic remains highly uncertain because, outside of a few intensively explored areas, the offshore Arctic remains essentially unexplored for petroleum, and geological evidence still suggests that significant volumes of undiscovered petroleum remain to be found outside the developed areas. The CARA estimated that 44 to 157 billion barrels (BBO) of undiscovered conventional oil and 770 to 2,990 trillion cubic feet (TCF) of conventional natural gas could be found north of the Arctic Circle (figs. 2, 3; table 1). In addition, large quantities of unconventional petroleum such as shale oil, shale gas, heavy oil, coal-bed gas, and gas hydrates might also be developable in the Arctic.

2. The geologically most likely places for significant volumes of undiscovered Arctic oil are probably onshore on the North Slope of Alaska, offshore in the U.S. Chukchi and Beaufort Seas, the Mackenzie River Delta in northwestern Canada, offshore northeast Greenland, and in the North Kara Sea and adjacent West Siberia in Russia (fig. 4). Russia, which already has enormous gas reserves, probably also has the largest resources of undiscovered conventional natural gasmost of it in the Arctic.
3. On an energy-equivalent basis, natural gas is much more abundant than oil in the Arctic. Yet-to-find recoverable conventional oil reported by the CARA, amounting to between 1.5 and 5 years of supply at current world oil consumption rates, is not large compared to the known resources at lower latitudes. The amount of gas resources estimated for the Arctic, on the other hand, represents about 30 percent of global undiscovered conventional gas, which is about 27 years of supply at current rates of consumption. However, large-scale production of natural gas in the Arctic is now generally unfeasible as a result of low gas prices, largely because of the development of unconventional gas resources in North America. As a result, most undiscovered Arctic gas would probably not be developed in the near future.

Should it take place, intensive oil and gas development could greatly affect the inhabitants of Arctic Canada, Greenland, and Russia; it is already affecting Arctic Alaska and northern Norway. New Arctic oil will also affect people south of the Arctic Circle. Oil in the Alaskan Arctic has been a big part of the North American oil marketplace for four decades and new discoveries in offshore Alaska and Canada would also feed growing global demand. Considered on a global scale, the high cost of working in the Arctic means that this northern oil will be another high-cost marginal source of supply, along with Alberta heavy oil and shale oil production in North Dakota and Texas, contributing comparatively small volumes to the global marketplace but greatly affecting world commodity prices. Its large undeveloped gas resource indicates that Russia will continue to derive political clout from energy resource development, and that natural gas will remain an abundant energy resource for decades to come. As global infrastructure for gas liquefaction and transport develops, the globalization of natural gas markets seems all but inevitable.

Throughout the discussions of these issues since 2008, the CARA resource estimates have been commonly cited as the authoritative evaluation of petroleum potential in the Arctic. The publication of this important collection of papers provides the background and supportive information for the CARA estimates of Arctic petroleum resources and a record of the reasoning that led the CARA scientists to those estimates. It is our intent that this volume will provide the documentation of the assessment process as transparently as possible such that the current understanding of energy resources north of the Arctic Circle can be fully communicated to audiences in government, industry, academia, and the media, as well as to future projects that seek to improve upon the CARA assessment results. 


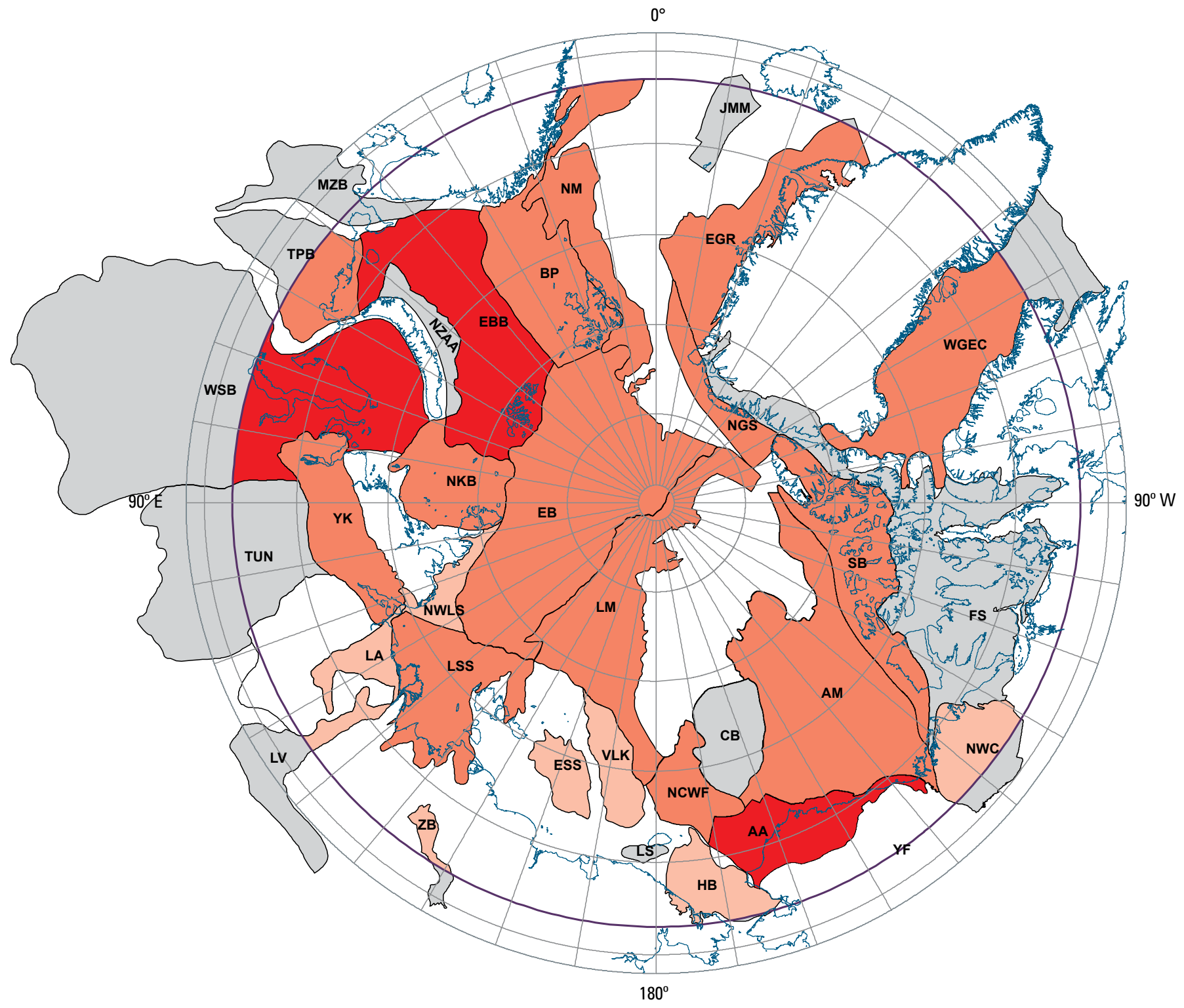

\section{EXPLANATION}

Undiscovered gas

(trillion cubic feet)

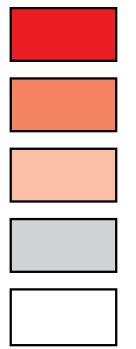

$>100$

6-100

$<6$

Area not quantitatively assessed

Area of low petroleum potential

Figure 2. Provinces in the Circum-Arctic Resource Appraisal color-coded by mean estimated undiscovered gas. Only areas north of the Arctic Circle are included in the estimates. Province labels are the same as in figure 1. 


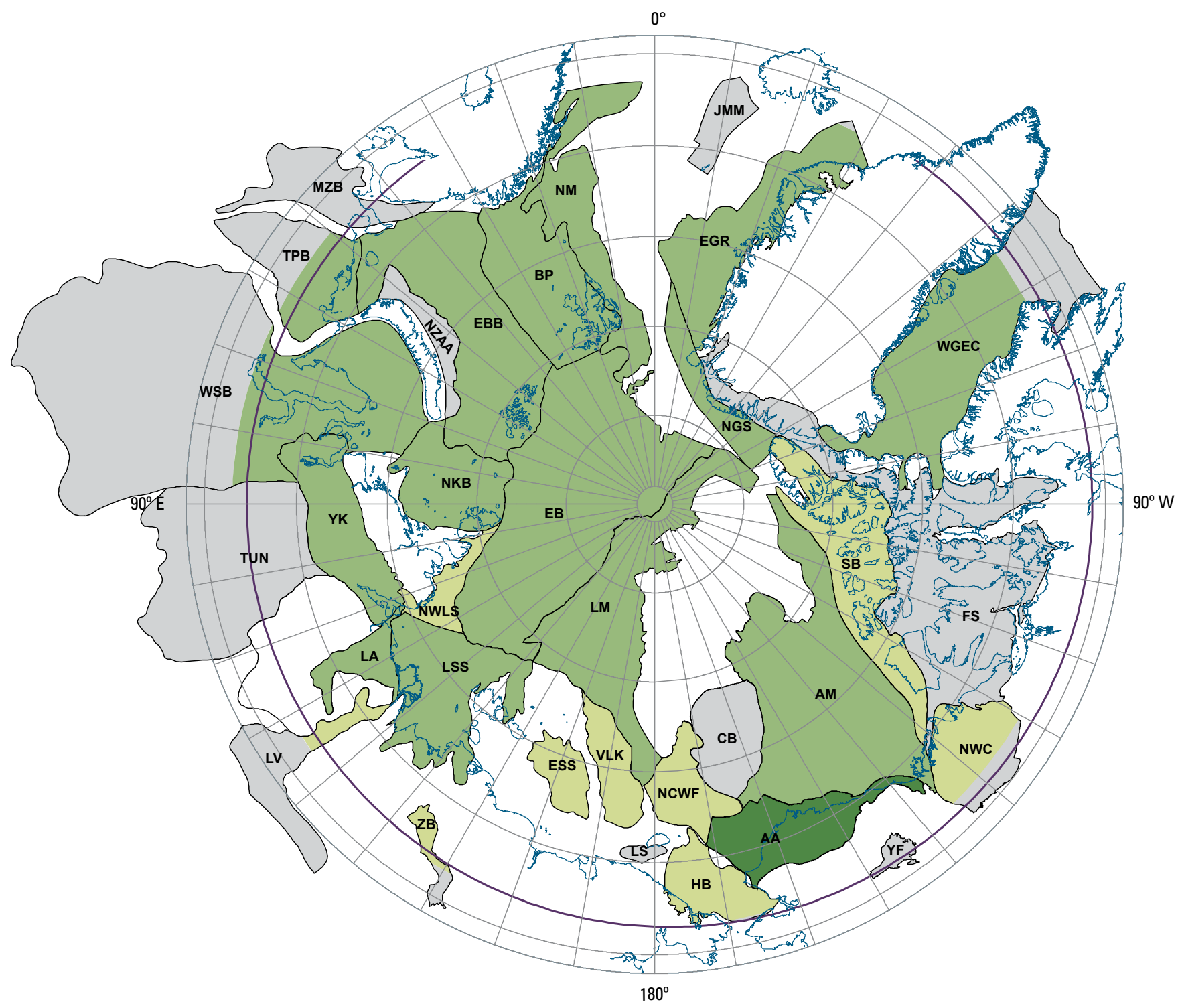

EXPLANATION

Undiscovered oil

(billion barrels)

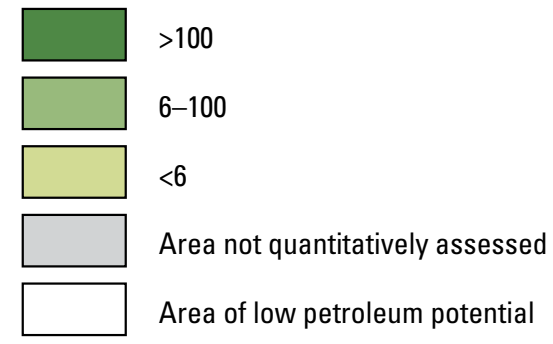

Figure 3. Provinces in the Circum-Arctic Resource Appraisal color-coded for mean estimated undiscovered oil. Only areas north of the Arctic Circle are included in the estimates. Province labels are the same as in figure 1. 


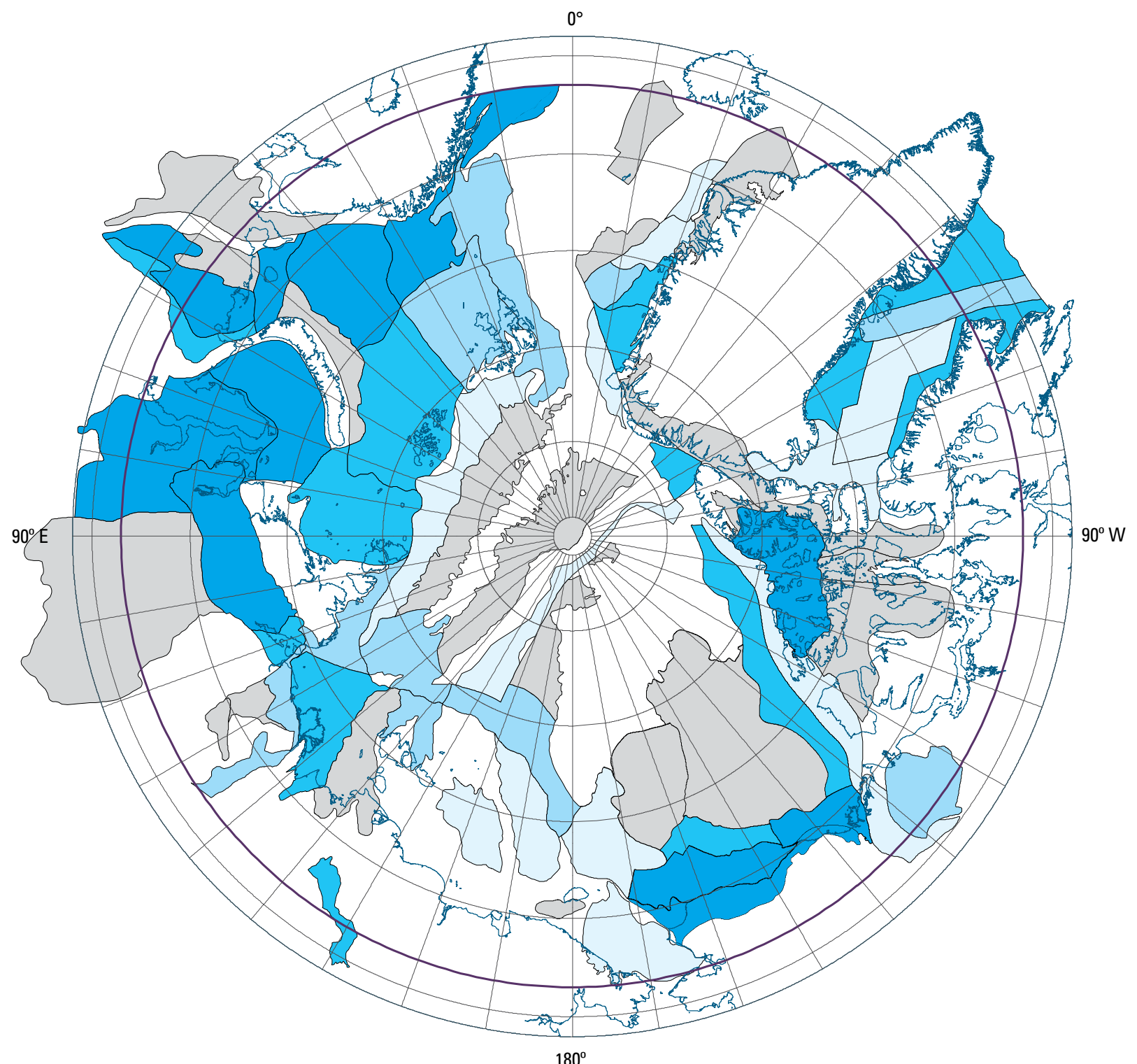

\section{EXPLANATION}

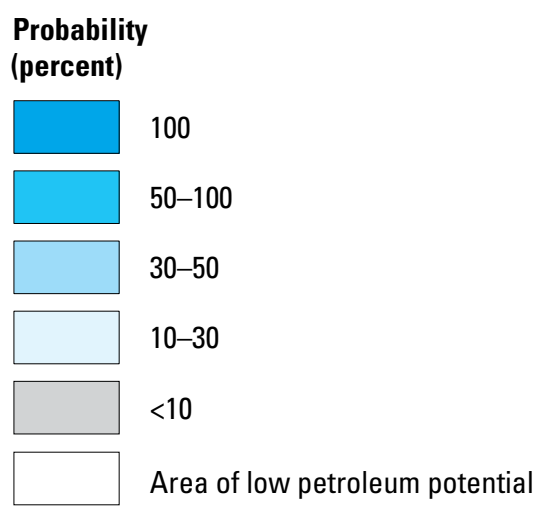

Figure 4. Assessment units in the Circum-Arctic Resource Appraisal color-coded by assessed probability of the presence of at least one undiscovered oil and (or) gas field with recoverable resources greater than 50 million barrels of oil equivalent (MMBOE). Probabilities for AUs are based on the entire area of the AU, including any parts south of the Arctic Circle. 
Table 1. Summary of mean estimates of undiscovered petroleum resources for the provinces of the 2008 Circum-Arctic Resource Appraisal.

[Province abbreviation refers to that used in figures 1-3. MMBO, million barrels of oil; BCFG, billion cubic feet of natural gas; MMBNGL, million barrels of natural gas liquids; NQA, not quantitatively assessed. Results shown are fully risked mean estimates. For gas accumulations, all liquids are included as NGL (natural gas liquids). Provinces are listed in ranked order of total barrels of oil and oil-equivalent natural gas (BOE)]

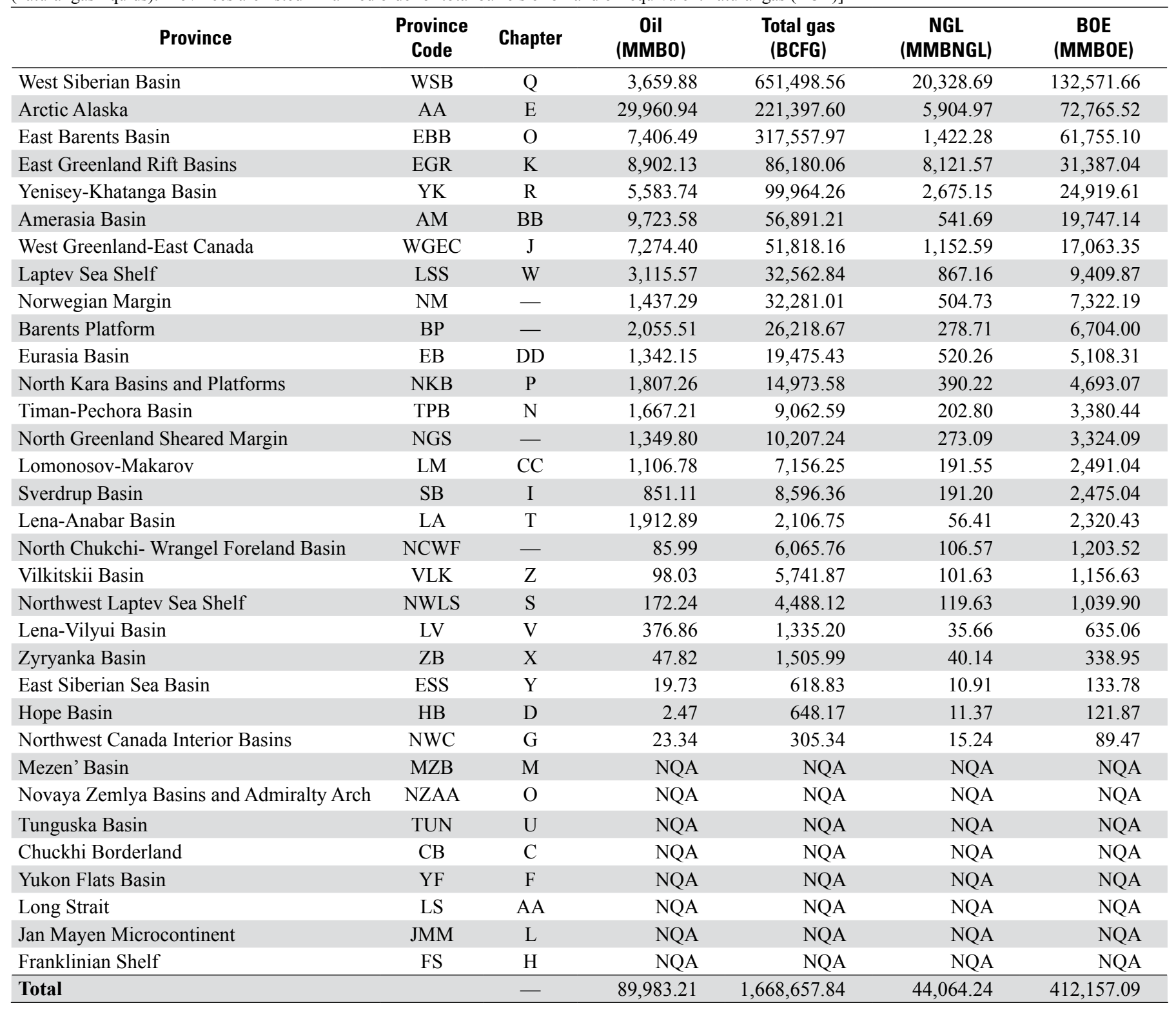




\section{References Cited}

Charpentier, R.R., Klett, T.R. and Attanasi, E.D. 2008, Database for assessment unit-scale analogs (exclusive of the United States): U.S. Geological Survey Open-File Report 2007-1404, 61 p., http://pubs.usgs.gov/of/2007/1404/.

Gautier, D.L., Bird, K.J., Charpentier, R.R., Grantz, A., Houseknecht, D.W., Klett, T.R., Moore, T.E., Pitman, J.K., Schenk, C.J., Schuenemeyer, J.H., Sørensen, K., Tennyson, M.E., Valin, Z.C., and Wandrey, C.J., 2009, Assessment of undiscovered oil and gas in the Arctic: Science, v. 324, p. 1175-1179.

Grantz, A., Scott, S.S., Drachev, S.S., and Moore, T.E., 2010, Map showing the sedimentary successions of the Arctic region $\left(58^{\circ}\right.$ $64^{\circ}$ to $90^{\circ} \mathrm{N}$ ) that may be prospective for hydrocarbons, $2 \mathrm{~d}$ ed.: AAPG Datapages, 78-p. pamphlet, 2 sheets, scale 1:6,760,000, accessed October 20, 2015, at http://datapages.com/gis-mappublishing-program/gis-open-files/geographic/sedimentarysuccessions-of-the-arctic-region-by-grantz-et-al-2010.

Grantz, A., Scott, R.A., Drachev, S.S., Moore, T.E., and Valin, Z.C., 2011, Sedimentary successions of the Arctic region $\left(65^{\circ}-90^{\circ} \mathrm{N}\right)$ that may be prospective for hydrocarbons, chap. 2 of Spencer, A.M., Embry, A.F., Gautier, D.L., Stoupakova, A.V., and Sørensen, K., eds., Arctic petroleum geology: Geological Society of London Memoir 35, p. 17-37.

Houseknecht, D.W., Bird, K.J., and Garrity, C.P., 2012a, Assessment of undiscovered petroleum resources of the Amerasia Basin petroleum province: U.S. Geological Survey Scientific Investigations Report 2012-5146, 36 p.

Houseknecht, D.W., Bird, K.J., and Garrity, C.P., 2012b, Assessment of undiscovered petroleum resources of the Arctic Alaska petroleum province: U.S. Geological Survey Scientific Investigations Report 2012-5147, 26 p.
Norwegian Petroleum Directorate, 2009, Petroleum Resources on the Norwegian Continental Shelf, 2009 [The Resource Report 2009]: Stravanger, Norway, Norwegian Petroleum Directorate, 48 p., accessed September 21, 2017, at http:// www.npd.no/en/Publications/Resource-Reports/2009/.

Peters, K.E., Ramos, L.S., Zumberge, J.E., Valin, Z.C., Scotese, C.R., and Gautier, D.L., 2007, Circum-Arctic petroleum systems identified using decision-tree chemometrics: AAPG Bulletin, v. 91, no. 6, p. 877-913.

Schuenemeyer, J.H., and Gautier, D.L., 2010, Aggregation methodology for the Circum-Arctic Resource Appraisal: Mathematical Geoscience, v. 42, p. 583-594.

Sørensen, K., Gautier, D., Pitman, J., Jackson, H.R., DahlJensen, T., 2011, Geology and petroleum potential of the Lincoln Sea Basin, offshore North Greenland, chap. 44 of Spencer, A.M., Embry, A.F., Gautier, D.L., Stoupakova, A.V., and Sørensen, K., eds., Arctic petroleum geology: Geological Society of London Memoir 35, p. 673-684.

Spencer, A.M., Embry, A.F., Gautier, D.L., Stoupakova, A.V., and Sørensen, K., eds., 2011, Arctic petroleum geology: Geological Society of London Memoir 35, 818 p.

U.S. Geological Survey 2009, Circum-Arctic Resource Appraisal (North of the Arctic Circle) Assessment Units: U.S. Geological Survey Energy Data Finder document 7C1E0B46-4DAF-901F-48EBA5492B06, accessed September 2017 at https://certmapper.cr.usgs.gov/geoportal/ catalog/search/resource/details.page?uuid=\%7B7C1E0B464DAF-4FE7-901F-48EBA5492B06\%7D.

U.S. Geological Survey, 2009, Circum-Arctic Resource Appraisal (North of the Arctic Circle) Assessment Units GIS Data. World Wide Web Address: http://energy.usgs.gov/ arctic/.
Menlo Park Publishing Service Center, California

Manuscript approved for publication November 7, 2017

Edited by Claire Landowski

Layout and design by Cory Hurd 


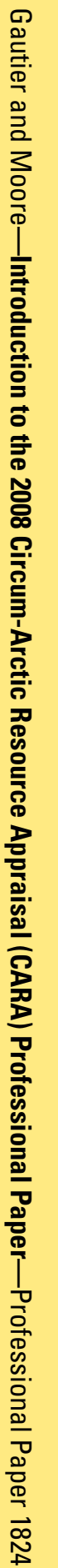

